\title{
Inter lingual influences of Turkish, Serbian and English dialect in spoken Gjakovar's
} language

\author{
Sindorela Doli-Kryeziu \\ (Professor at University of Prishtina) \\ $\mathrm{PhD}$ in Linguistics, \\ Specialization on Dialectology / Sociolinguistics field \\ sindidol@yahoo.com \\ Gentiana Muhaxhiri \\ Phd.candidate on Albanalogy \\ gentianamuhaxhir@hotmail.com
}

Abstract

\begin{abstract}
In this paper we have tried to clarify the problems that are faced "gege dialect's" speakers in Gjakova who have presented more or less difficulties in acquiring the standard. Standard language is part of the people language, but increased to the norm according the scientific criteria. From this observation it comes obliviously understandable that standard variation and dialectal variant are inseparable and, as such, they represent a macro linguistic unity. As part of this macro linguistic unity and by sociolinguistic terms view, members of linguistic community speakers, through changes in phonemic and sub phonemic in toggle sounds, at the same time reflect on the regional and social affiliation background of the speaker. Gjakova is the city where fossils have remained as slang interlingual influences of Turkish language, Serbian language and after the war in Kosovo is very widespread of English slang. The methods we have used in the treatment of our case have been supported on the work and the survey, observation and interpretation. We tried to bring a clearer picture of speaking variation reports, in our case of Albanian speaking language, always when we deal with the extension of standard language in Gjakova town. The method of research and interpretation is the most predominant method in this survey, while an important place in the treatment of this topic is given to methods of surveying / questionnaire about the extent of the standard language in Gjakova town. We have done a comparison of standard Albanian language examination and other languages situations as well, which have a longer tradition of standard language, furthermore countries that have similar development situations with the Albanian standard language.
\end{abstract}

Keywords: Gege dialect's, Gjakova, Standard language, interlingual of turkish language, serbian language and english slang.

\section{Introduction}

The target study of this paper is today's Albanian language against involvement of unnecessary usage of foreign vocabulary items. This is not a new concern, but it is old as language itself and today has taken huge unnecessary dimensions without valuable reasons. Regarding this topic we have studied what was written until now, we have observed both two countries newspaper, designation of both Tirana's and Prishtina's public environments, all we have heard everyday in the radio, TV and daily conversations, if the number of unnecessary borrowed words (neologism) was added or reduced. This paper will treat the issues such as: What is current situation of Albanian language in our two countries; Why are so many foreign words included in our language; Which are the ways that induce this inclusion; What can we do to reduce this phenomenon.

\section{Material and methods}

In the last years it has been noticed a deformity of our language due to the large invasion of unnecessary foreign words and syntax and morphological construction unsuitable for Albanian language. We can certainty say that what we speak and hear is not Albanian language, but it is a beautiful language that once existed, mixed with range of words and elements of foreign languages. We speak with certainty about this mix, since a lot of people express their concern that they do not understand vocabulary items they do listen in the radio or TV, or they read in the newspapers and magazines. 
Beside information tools such as radio, TV, newspapers and magazines, unnecessary foreign words have been included also in designation of public environments. It is sufficient to take a look the Tirana's streets, when only in one side of the street called "Abdyl Frasheri" from 54 environments, 36 of them are labeled using foreign language, 12 (twelve) of them are labeled in foreign and native language and only 6 (six) out of 54 (fifty-four) are labeled in native or Albanian language. The same problem stands for Prishtina too where the designation public environments in foreign language prevail. What is noticed is the designation of public environment where people receive the medical drugs by doctors. In Tirana and everywhere in Albania these places are called "farmaci", while in Prishtina and in Kosova generally are called "barnatore", while in Tirana was found only one place where the name "barnatore" was used accompanied with two other names "farmaci" written in Albanian and "pharmacy" written in English language.

Everywhere, in all places in Kosova and Albania, continuously you can hear the use of foreign words, respectfully the use of English language words, vainglorious that they are the only one that "speaks this kind of language". This phenomenon deals with their inferiority for English language knowledge, so they include foreign words inappropriately in Albanian language, or simply this is a consequence of globalization that is affecting all languages worldwide except Englishspeakers!

We know that the Albanians for centuries have tried to eliminate foreign expressions from already known historically rulers, with special dedication in the interest of purity of Albanian language from cross-linguistic influence. It grew more and more vigorously during Albanian National Renaissance and it can be surely said that is always current and continues to be even today, because native language deserves constant attention.

The use or substitution of new word in target language can affect in three ways ${ }^{1}$ :

1. The meaning of new word could be confusing with the meaning that existed earlier in the certain language.

2. The word that existed earlier in the certain language can disappear.

3. New and old word can survive but each with special meaning.

Another problem is orthography of foreign words, since we find them written as are written in the language where these words came from, but phonetically are not appropriate, for example floppy, boss, advocacy, web, window, mouse, etcetera.

In case of non inflectional proper nouns as foreign language impact which is known regarding to Albanian language grammatical structure that it does not occur as a result of foreign language impact. For example, words: "Watson", "Jeopardy", "Galaxy" ("Koha ditore" January 16 th '11, pg.20), "Jimmy Cartes", or title ( in the same place), "Miqtë e kujtojnë me humor Holbrooken", following other politicians names "Hilary Clinton", or "Blair ngulmonte për ndërhyrje tokësore në Kosovë", "...Ambasadori I SHBA-së në Prishtinë Christofer Dell", "Intervistë me Pieter Feith", etc.

In Albanian language there are also cases of foreign words borrowing, even though those words exist in Albanian language with the same meaning, e.g. "U caktua bordi këshillues", "Ishte një njeri mjaft i ndjeshëm dhe mjaft sensibël", "Ishte një tentativë për orvaitje...", " U implementua dhe u zbatua plani tre mujor", " Prioritet me përparësi kishin minoritetet në Kosovë...., etc.

There are also borrowed foreign words which posses' suffix - ment, that are introduced into grammatical aspect, for example. "Apartament", "Departament", "Statement= steitmenti", etc.

Borrowed foreign words with prefix post-, which in Albanian can be used the word pas-, e.g. "U mbajt fjala post-mortum për ...", "Studimet postuniversitare...". We have prefix- super, e.g. "Superman", "Superfamilje", etc.

Borrowed words that deals with $\boldsymbol{b i}$, e.g. "Bilateral", "Biseksual", "Bipartiak", etc.

There are also borrowed words from compounds, and there are three types:

1. Compounds elements can be borrowed as for example: "Spiderman", "Autostop", "Autostradë", etc.

2. Compounds elements taken from foreign language that can be substitute in Albanian language, e.g. No problem" ( S'ka problem), "OK" ( mirë), etc.

3. Elements can be transferred to the recipient language, while others substituted.

1 Uanrah Juriel "Interferenca leksikore", Ndikime Ndërgjuhësore përgatitur nga Vesel Nuhiu, Rilindja, Prishtinë, 1990, fq.74-79. 
There are morph-syntactic errors or mistakes, using prefix-për. për momentin, which is taken from English pattern for the moment, while we have ours expressions as : hë për hë, tani pë tani , etc. are. Another English expression is used on Economic field, e.g. Dola për shoping ( Dola për të blerë), A do ta paguash me para kesh? ( A do të paguash me para në dorë). Than we have English adverb full, that is usually used by young people: Ishte kafiqi full ( Ishte lokali i mbushur plot). In this sentence we notice word "kafiqi" borrowed word from Serbian in Kosova, whereas in Albania people use word 'Lokali ishte full'.

Always, we consider the establishment of linguistic culture, social and historical. We should be aware that due to modern technology development, a lot of foreign words are included in our daily vocabulary talk, since so far we have not made any discovery so we could named it in Albanian language.

Thinking how could our language look like in the future, considering the current rhythm of unnecessary borrowings of foreign words and if we do not give our full efforts to protect it, then we should be prepared for the worse, which is losing it.

Then questions arise: why must we feel uncertain in what we understand from the readings and what we listen in Albanian language? Being Albanian and living in our country, why should we learn several foreign languages to achieve an accurate communication with our fellow-nations?

However, about enrichment and purity of standard Albanian language or spoken language in Kosova and Albania, we must consider the scientific carefulness. It means, that in cases when it is possible to avoid the usage of foreign borrowed words that do not have special or important function, we should follow this criteria. And vice versa, if there is no appropriate Albanian word we notice better attitude for foreign language words. Below we will present several methods how to prevent this phenomenon.

We may use media as a tool to bring information of how should we speak and write our native language accurately, purely, clearly and beautifully. This can be accomplished by transmitting a radio or television show for daily and essential language issues in order to preserve the language as best we can and to adapt it with nowadays requirements in a proper way without deforming it.

Also, the respective papers can dedicate a special article considering this issue once a week, where linguists can write about the best ways of Albanian language usage, provide orthographic rules and specify the borrowed foreign words that we speak and hear and their substitutions.

There can be organized trainings for the teachers who teach Albanian language in high schools, pre-university education, since they are the first and main persons who provide accurate knowledge in Albanian language as school subject.

A special attention should be given to the translators and the books they translate. The translator should not have only the best knowledge on the foreign language, the language that the book is written and needs to be translated, but he/she should have the best knowledge of Albanian language, enriched lexicon, knowledge on morphologic and syntactic construction, on phraseology and best knowledge on orthographic rules.

To different private subjects, before they receive a license to start an activity, should be strongly require the use of pure Albanian language for naming of their activity.

It is important and necessary establishment of state institution who will protect the language and take penalty measurements to those who do not use the language according the certain rules.

Today we live in a free world where each has the right to express their opinion, but no one has the right to deform the language, a wealth that belongs to all, only because that person has a public position whose words are to be listen by a great number of people and uses them (the foreign words) only because he assumes they are trendy.

It is true that Albanian language needs to be enriched with new words, but these words should not be taken misguidedly as one wishes, but should be very careful and see if these words are really enriching our vocabulary. More than ever, today the society is absorbed by the globalization therefore we need to give our best and work to protect and enrich our language and prevent its assimilation. So we need to take foreign words to fill the gaps present in our native language by always adapting conform the language structure and avoid reception of foreign words which already exist in Albanian language.

It is very important to work together since we all have the same purpose, to retain and protect standard Albanian language from unnecessary foreign words, syntactic and morphologic construction inappropriate for our language. 
We should all use inexhaustible sources of words found demotic language and through a stone in our ancient and beautiful castle of Albanian language, by enriching it and adapting it conform today's requirements.

\section{Results}

Based on this study we confirm that there is a huge dimension of unnecessary borrowings of foreign words in both our countries, Kosova and Albania, and the ways these words enter in our vocabulary are through media, incorrect translations, the will of Albanian speakers to include foreign words in their daily communication with each other, often without knowing accurate meaning of the used word. This desire for foreign language unfortunately is reflecting in all fields, such as: vocabulary (lexicon), morphology, syntax.

As we may notice, these formation belong more or less to informal language incorporated to formal language, which we have heard and read in our media which unfortunately are deforming the foundation of Albanian language, as the writer Amosz Osz, states " gjuha e kontaminuar e ka fuqinë shumë herë më të madhe se bomba bërthamore, sepse helmon disa breza".

\section{Discussion}

It is true that Albanian language needs to use new words, but these words should not selected as one desires, but we need to be more careful and pay full attention to estimate if these words enrich or damage our language. It is true that Albanian language needs to be enriched with new words, but these words should not be taken misguidedly as someone may wish, but we should be very careful and see if these words are really enriching or damaging our vocabulary. More than ever, today the society is absorbed by the globalization therefore we need to give our best and work to protect and enrich our language and prevent its assimilation. So we need to take foreign words to fill the gaps present in our native language by always adapting conform the language structure and avoid reception of foreign words which already exist in Albanian language.

It is very important to work together since we all have the same purpose, to retain and protect standard Albanian language from unnecessary foreign words, syntactic and morphologic construction inappropriate for our language.

We should all use inexhaustible sources of words found demotic language and through a stone in our ancient and beautiful castle of Albanian language, by enriching it and adapting it conform today's requirements.

\section{Conclusion}

Based on what we have studied we can conclude that it is very important to work together for the same purpose, to retain and protect standard Albanian language from unnecessary foreign words, syntactic and morphologic construction inappropriate for our language.

We should all use inexhaustible sources of words found demotic language and through a stone in our ancient and beautiful castle of Albanian language, by enriching it and adapting it conform today's requirements.

\section{Reference}

[1] Xhuvani A, (1956) Për pastërtinë e gjuhës shqipe, Tiranë

[2] Rrokaj Sh, (2007) Çështje të gjuhës shqipe,Tiranë

[3] Rrokaj Sh, (2005), Hyrje në gjuhësinë e përgjithshme, Tiranë

[4] Xhuvani A,(1956), Për pastërtinë e gjuhës shqipe, Tiranë

[5] Shkurtaj Gj,(2006), Kultura e gjuhës, Tiranë

[6] Cabej E, (1981), Për pastërtinë e gjuhës, Gjuha jonë 1,

[7] Shkurta, Gj, (2010), Shqipja e sotme, Tiranë

[8] Historia e letërsisë shqipe I-II, 150-151 
[9] Kelmendi, T, ( 2006), Kështjellat e Sintaksës, IAK, Prishtinë

[10] Lloshi, Xh, (2009), Ndërhyrja e huazimeve nga anglishtja, Seminari III Ndërkombëtar i Albanologjisë në Tetovë

[11] Muja H, \& Doli-Kryeziu S, (2010), Diktohet në qendrim më i lirë rreth purizmit IAK, Prishtinë

[12] Thomai J, (1984), Leksikologjia e Gjuhës Shqipe, Tiranë

[13] Mulaku R(2010), Disa ndikime të anglishtes dhe të serbishtes në gjuhën shqipe, IAK, Prishtinë

[14] Uanrah J, (1990), Interferenca leksikore, Ndikime Ndërgjuhësore përgatitur nga Nuhiu V, Rilindja, Prishtinë 